\title{
光過敏症におよぼす光の程度の影響
}

\author{
礒 部 明 彦, 木 村 修一 \\ 東北大学農学部栄盖化学教室
}

\section{Effect of Light-Intensity and Irradiation Way on Hypersensitiveness by Photodynamic Agent $\dagger$}

\author{
Akihiko ISOBE, Shuichi KIMURA \\ Laboratory of Nutrition, Faculty of Agriculture, Tohoku University, Sendai
}

\begin{abstract}
For the development of hypersensitiveness caused by pheophorbide, light exposure is an essential factor. This paper deals with the effects of the intensity and irradiation schedule of the light on the development of the hypersensitiveness. When $5 \mathrm{mg}$ pheophorbide in $0.5 \mathrm{~m} l$ dimethylsulfoxide were injected into the rat's peritoneum -and exposed to visible light $(100 \mathrm{~V}, 300 \mathrm{~W})$ for $5 \mathrm{hr}$, the rats were dead. However after injection, when the rats were kept in complete darkness for exactly $6 \mathrm{hr}$, the rats were survived. It was not observed that the dosage of pheophorbide fed per os during a long period caused the deposit of the material. We found that the photodynamic sensitization of hypersensitiveness did not depend on the eyeballs but on the extent of epiderm. In order to compare with the full-haired rats they were depilated one-half. But the effect of depilation was not observed.
\end{abstract}

(Received January 17, 1976)

光過敏症といら現象は最近とくに注目されているが， この原因には医薬品》のような化学薬品を投与した場合 と，食品中に含有される光活性化学物質が皮庙炎 ${ }^{22 \sim 4)}$ の よらな症状をひきおこす光過敏症とが知られている5。 光過敏症には種々の原因物質が関与しているが，薬品 による過敏症と食品による光過敏症との間には，なんら かの類似性のあることが推剆される。しかし，これらの 光過敏症のメカニズムについて言及している報告は少な (.5)。

著者らは, この光過敏症の発現とそのメカニズムを追 究するため, 本研究をはじめ前報 ${ }^{6)}$ において, へオホー ハイドによる光過敏症の発現をウィスター系ラットにつ いて钼察し，耳の脱落といら結果をえた。

本報においては，光過敏症発現におよぼす光照射の強 さおよび照射方法について検討をおこなったので報告 する。

\section{実験材料および方法}

\section{1. 試料の抽出}

実験に供したへオホーバイドは，市肘の野沢菜渍をホ

†光力学的物筫による過敏症成立とそのメカニズム (第2 報)

$\dagger$ Appearance of Hypersensitiveness by Photodynamic Agent and Its Physiological Mechanism (Part II)

广 980 仙台市堤通雨宮町 1-1
洗し，凍結乾燥ののち粉末化したものから，前報6)のよ らな抽出方法により得られた。

\section{2. 実験動物}

前報6) の実験条件において，実験に使用したネズミ類 が 100\% 致死したので，本報ではそのらちから，ウィス ター系雌白ラットを選んで使用した。

\section{3. 光照射装置}

光照射装置は橋本ら”と同じ装置を作製し使用した。 なお，光源として，レフランブ, フラッド 300 ワット (松下電器製) を用い, 飼育ヶージの温度を $25^{\circ} \pm 1^{\circ}$ K するため，ランプとケージの中間に水深 $5 \mathrm{~cm}$ のガラス 製水槽を設け，常時水道水を流し，照度はガラス製水槽 下において1万ルックスとし，暗所での実験について は, ネズミ飼育ケージ全体を黒い暗幕で被って行なっ た。

\section{実験結果と考察}

光過敏症の発見に光照射と遮光との時間的関係がどの ように作用しているかを知る目的で，以下の検討を加光 た。

\section{1. 光過敏症発現におよばす光照射時間の影響}

前報6) の抽出方法より得られたへオホーパイト $5 \mathrm{mg}$ をジメチルスルホキサイド(以下, DMSO と略す。この 溶媒はラットにおいて体重 $200 \mathrm{~g}$ 当たり, $2 \mathrm{~m} l$ を腹腔 
注射しても異常はなかった） $0.5 \mathrm{~m} l$ に溶解し, 体重約 $150 \mathrm{~g}$ のラットの腹腔に注入, 注入後, $0.5,1,2,3$, 4, 5 および 6 時間, 照度 1 万ルックスの可視光線を照 射したのち,つぎに，暗所で継続飼育した。その結果， $0.5,1,2,3$ および 4 時間照射ラットはなんの異常も認 められなかったが， 5 および 6 時間照射ラットは照射後 それぞれ 5 時間， 3 時間後に死亡した。この実験にはラ ット 3 匹ずつ供し，3回実験をくり返したが再現性はき わめてよかった。

$0.5,1,2,3$ および 4 時間照射群では，つぎの暗所 飼育時間が何時間になってもなんら異常は認められなか ったことより，ーオホーバイドといら光過敏症物質が 4 時間の光照射時間で恬性化されなかったためか, 組織 への十分量の蓄積には時間が少なかったためと考えられ る。

なお， 5 および 6 時間照射群では, へオホーバイドの 生体内での浱度が最高に達し, その時点で光の照射を行 ならと，照射によって致死量に達する程度のへオホーハ イドの活性化がなされた結果, 死亡したるのと思われ る。

これらの結果は Table 1 に示したが, 5 時間照射と 6 時間照射とを比較すると, 5 時間照射ラットは照射後 5 時間, 6 時間照射ラットは照射後 3 時間で死亡するこ とから、へオホーパイド量を $5 \mathrm{mg}$ と一定にした場合， 死亡防止に 4 時間照射が限度であり, また 5 時間以上の 照射時間は, 死亡するまでの時間と逆比例する可能性が ある。すなわち, 光照射時間をもっと長くすれば, 死亡 するまでの時間をもっと短縮できるるのと推定される。

\section{2. 光過敏症発現におよぼす暗所時間の影敀}

ヘオホーハイド $5 \mathrm{mg} / 0.5 \mathrm{ml}$ (DMSO) を約 $150 \mathrm{~g} の$ ラット腹腔に注入, 注入後, $0.5,1,2,3,4,5$ および 6 時間暗所で飼育し, 各暗所飼育時間後 1 万ルックスの 光照射をおこなった結果， $0.5,1,2,3,4$ および 5 時 間暗所飼育ラットは，それぞれ，5，5，5，6，6および 6 時間後に死亡した。しかし，6時間暗所飼育ラットは 死亡しなかった。結果は Table 2 に示したが, 暗所飼 育時間が 6 時間以上になると, 暗所時間中に一オホーハ イドが代謝, 排泄されてしまい, 光照射時にはすでに光 力学的作用をあらわす活性化へオホーパイドが致死量に いたらなかったためと思われる。暗所時間が 5 時間まで は，死にいたらしめる有効量が体内に存在していること を示している。活性化されたへオホーパイドがどのよう な構造を有しているのかは確かではないが、へオホーハ イドが光を夢収して、よりェネルギー準位の高い所に励 起 (励起一重項状態)されて, 光增感剤) として作用し, さらに, エネルギー準位の中位の位置(励起三重項状態) で生理活性を表わしている可能性も考えられる22。これ
Table 1. Influence of irradiation time (hr).

\begin{tabular}{cc}
\hline Irradiation time (hr) & Survival time (hr) \\
\hline 0.5 & $\infty$ \\
1 & $\infty$ \\
2 & $\infty$ \\
3 & $\infty$ \\
4 & $\infty$ \\
5 & 5 \\
6 & 3 \\
\hline
\end{tabular}

Mean value of 3 rats.

Table 2. Influence of the period from injection of the agent to irradiation of light.

\begin{tabular}{cc}
\hline Dark time (hr) & Survival time (hr) \\
\hline 0.5 & 5 \\
1 & 5 \\
2 & 5 \\
3 & 6 \\
4 & 6 \\
5 & 6 \\
6 & $\infty$ \\
\hline
\end{tabular}

Mean value of 3 rats.

らの過程から考えると, 一オホーバイドなどの光過敏症 発現物質等には, すべてケイ光が観察されるといらこと は重要なことであると思われる8。

3. ヘオホーパイドの体内蕃皘についての検討

上記 1,2 のごとく，抽出へオホーバイドを直接腹腔 に注入した場合, 適当な光照射時間が存在すれば光過敏 症は発現するといらことが確認されたが，暗所でへオホ 一ハイドを長期間経口投与し，その後，光照射した場合 の影響を検討するため，暗所で乾燥粉末野沢莱渍を固型 飼料に $15 \%$ の割合で混合して与え，1，2，3 週間後に 普通飼料に切り替省ると同時に，ガラス製水槽下にょけ るラットに1万ルックスの光照射をおこなった。

体重変化は Fig. 1 に示したように, 体重の上昇が普 通餇育ほど良好ではないが，ほとんど变化が見られず， 外見上であ光過敏症の徴候は認められなかった。

これらのことは，へオホーバイドを光過敏症を発現す るに必要な浱度にまで投与して 3 週間暗所で飼育してる その作用物質が蓄箖することがないことを示している。

4. 光感受性部位としての眼球の役割

光過敏症の実験において，ラットが光を感受する部位 


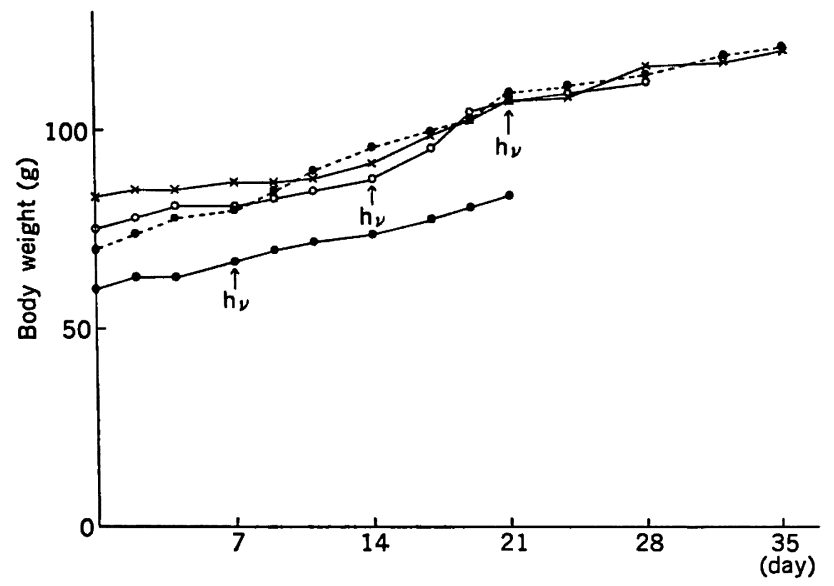

Fig. 1. Growth curve of experimental animals.

- - 1 week dark, - -2 week dark, $-x-3$ week dark, - - - - control. average of 3 rats, $h_{\nu}$ : irradiation start.

として考えられるのは，皮庙と眼球である。そこで，光 過敏症とい5現象が皮庙を媒介として光を体内に導入し ているのか否かを確認する目的で,つぎのような実験を おこなった。すなわち，ラットの両眼に $1 \mathrm{~N}$ 水酸化ナ トリウム溶液を滴下し，角膜を破壊したのち， $5 \mathrm{mg} / 0.5$ $\mathrm{m} l$ (DMSO) へオホーパイドを腹腔に注入した。コント ロールとしては同様に処理したラットの腹腔に $0.5 \mathrm{ml}$ の溶媒の DMSO だけを注入し，両方の実験群に1万ル ックスの光を照射した。その結果, 実験群は約 6 時間で 死亡したのに対し，対照群にはまったく異常は見いだせ なかった。

このことは，両眼角膜破壊したラットでるへオホーハ イドを注入し，光照射をおこなえば死亡するということ から, 光感受性に眼球刺激は必要ないという可能性が示 唆された。

\section{5. 光過敏症発現におよぼす体毛の影響}

光感受性部位としての眼球の重要性が否定されたの で,つぎに，皮庙の検討を怙こなった。実験群，対照群 ともに各 3 匹のラットを用いた。

ラットの背の中央を約 $1 / 2$ 除毛（資生堂製へアリムー バーを塗布後, バリカンにて眖毛)し，皮庙を露出した。 このラットに, ヘオホーハイトト $5 \mathrm{mg} / 0.5 \mathrm{ml}$ (DMSO) を腹腔に注入し，脱毛処理をしなかった対照と比較し， 死亡時間の短縮が観察されるかどらか検討した結果, 死 亡時間の短縮は観察されず, 皮成露出度が光過敏症にお。 よ洔す影響は少ないものと思われる。 この点に関しては, 今後 $1 / 2$ 以上の割合で除毛したラ
ット，あるいは，さらにへフレスマウス等を使用して検 討する考えである。

\section{要 約}

体重 $150 \mathrm{~g}$ の催ラットにーオホーパイト $5 \mathrm{mg} / 0.5 \mathrm{~m} l$ (DMSO) を腹腔注入した場合, 最低 5 時間の 1 万ルック スの光照射があれば死亡することが確認された。

なお，光過敏症発現におけるへオホーバイド投与から 光照射までの時間を検討したところ，投与後 5 時間まで は死亡するが，6時間をすぎるとその効果がなくなるこ とが明らかとなった。

また，へオホーパイドを長期にわたって経口投与して も，必ずしも蓄積効果はみられなかった。

さらに，光感受性部位としての眼球の役割はほとんど ないことがわかった。それに，皮有露出度の影響むあま りないように思われた。

\section{文献}

1) 橋本芳郎, 堤 淳三 : 食衛誌, 4, 185 (1963)

2) Cromroy, H.L.: Genetics., 46, 860 (1961)

3) Wolff, S. and Luippold, H.E.: Photochem. Photobiol., 4, 439 (1965)

4) Blum, H.F.: Princeton University Press, Princeton, N.J. (1959)

5) Pathak, M.A.: J. Invest. Dermat., 37, 397 (1961)

6) 礒部明彦, 木村修一：栄養と食糧, 投稿中

7) 山田幸二: 栄養と食糧, 27, 317 (1974)

8) Armstrong, J.A.: Exptl. Cell. Res., 11, 640 (1956) 